\title{
Boşanma Davalarında Çocuğun Velayet Hakkı İçin Uygun Ebeveynin Belirlenmesi
}

\author{
Determining the Suitable Parent on Children's Custody Cases
}

\author{
Ishak Kalkavan, Erhan Büken \\ Başkent Üniversitesi Tıp Fakültesi Adli Tıp Anabilim Dall, Ankara
}

\begin{abstract}
Özet
Boşanma davaları ülkemizde her geçen yıl artan sıklıkta görülmektedir. Bu davalarda başvuran çiftlerin eğer çocukları varsa davalarda bir de çocuğun velayetinin kime verileceğinin belirlenmesi gerekmektedir. Bir çocuğun gelişimini sağlıklı bir biçimde tamamlayabilmesi için ebeveyn, ebeveynliğin gereklerini yerine getirebilmelidir. Ebeveynin ebeveynlik becerilerini uzun dönemde "yeterince iyi" şekilde yerine getirebilme düzeyi ebeveynlik kapasitesi olarak adlandırılır. Çocuğun velayetinin hangi ebeveyne verileceğinin belirlenmesinde göz önünde bulundurulması gereken önemli unsurlardan biri de ebeveynlerin ebeveynlik kapasitesinin değerlendirilmesidir. Değerlendirme için hâkim bilirkişiye başvurabilir, burada bilirkişinin düzenleyeceği raporun amacı velayet kararını verirken hâkime yardımcı olmaktır. Yapılan değerlendirme, velayetin kime verilmesi gerektiğini belirtmekten çok ebeveynlerin var olan durumunu ortaya koyar. Çocuğun korunması bağlamında yapılan ebeveynlik değerlendirmesi ebeveynlerin klinik değerlendirmelerinden veya ebeveynlik eğitiminden farklı bir kavramdır çünkü bu değerlendirme adli süreçlerde kullanılacaktır. Literatürde ebeveynlik kapasitesi değerlendirmesinde profesyoneller tarafından aktif olarak kullanılan çeşitli değerlendirme araçları vardır. Bu araçlar birbirlerinden küçük farkl1lıklar gösterebilmektedir. Genellikle değerlendirmede hangi aracın kullanılacağı bilirkişinin insiyatifine bırakılmıştır ancak aracın uygulandığı toplumun yapısına uygunluğu gözetilmelidir. Makalemizde ebeveynlik kapasitesi değerlendirmesi için kullanılabilecek objektif ölçütlerin neler olabileceği tartışılmaktadır. Değerlendirmede kullanılabileceği savunulan iki (Parenting Skils Assessment-10; Parenting Competence 3) aracın özellikleri irdelenmiştir.
\end{abstract}

Anahtar Kelimeler: Ebeveynlik; Ebeveynlik kapasitesi; Velayet.

\section{Giriş}

Boşanma davaları ülkemizde her geçen yıl artan sıkl1kta görülmektedir. 2006 y1lında 95.853, 2007 y1lında 98.396, 2008 y1linda 103.081 ve 2009 y1linda 117.107 , 2010 y1lında $122.486,2011$ y1lında 125.254 ve 2012 y1-

\section{Sorumlu Yazar: İshak Kalkavan}

Başkent Üniversitesi Tip Fakültesi

Adli Tip Anabilim Dal, Ankara

E-posta:kalkavanishak@gmail.com

Geliş:24.12.2015 Düzeltme:22.01.2016 Kabul:14.03.2016

\begin{abstract}
The rate of divorce cases has projected an increasing number in recent years. In these cases, if couples have children and are demanding a divorce, a settlement should be done about which parent should have the custody of the children. A parent ought to carry out his/her parenting responsibilities so that the children would complete their developmental process in a healthy and sufficient environment. The level of fulfillment of parenting skills in long term "good enough" by parents is called parenthood capacity. One of the most important points to take into consideration while deciding on a custodian is the assessment of parenthood capacity. For an accurate assessment, judge might consult a referee. The aim here is to assist the judge to reach a verdict on custody assessing the reports run by the referee. This assessment demonstrates parents' current situation rather than their eligibility to be custodian. Since parenthood assessment, regarding protection of child, is used during judicial process, it is a different notion from clinical examination of parents or parenthood education. There are various assessment tools on parenthood which are actively used by professionals in the literature. These tools might slightly differ from each other. It is usually under the initiative of referee to choose the right tool for an assessment. However, it is essential to pay regard to the social norms of that particular society while choosing an assessment tool. This article will discuss the possible objective standards to use for assessing parenthood capacity. The features of two tools, which are claimed to be feasible for use in an assessment (Parenting Skils Assessment-10; Parenting Competence 3), will be studied.
\end{abstract}

Keywords: Parenting; Parenting Capacity; Custody. lında 120.333 boşanma davası açılmıştır (1). Bu davalarda başvuran çiftlerin eğer çocukları varsa davalarda bir de çocuğun velayetinin kime verileceğinin belirlenmesi gerekmektedir.

Çocukların refah içinde yaşamaları ve gelişimlerini sağlıklı bir ortamda tamamlamaları Birleşmiş Milletler Çocuk Hakları Sözleşmesi gibi uluslararası düzenlemeler ve ülkelerin kendi yasalarıyla güvence altına alınmıştır. Birleşmiş Milletler Çocuk Hakları Sözleşmesi çocuğun yetişmesi ve gelişiminden öncelikle anne ve babasının sorumlu olduğunu vurgular. Ayrıca çocuğun kişiliğinin tam 
ve uyumlu olarak gelişebilmesi için mutluluk, sevgi ve anlayış ortamında büyümesinin gerektiğini belirtir. Fakat bu süreçte sadece aile değil diğer profesyonellere de (Sosyal hizmet uzmanları, Psikologlar, Pediatristler, Pedagoglar, Öğretmenler ve Adli tıp uzmanları) (2-4).

Boşanmış ailelerde çocukların psikolojik iyilik durumlarında bozulma (Depresyon, Anksiyete gibi), akademik başarı ve sosyal uyumlarında diğer çocuklara göre düşüş gözlenmiştir. Bu olumsuz etkiler çocukların yetişkinlik hayatlarına ve hatta evlilik hayatlarına da etki etmektedir (5). Çocuğun, boşanma sürecini ve devamında geçecek olan zamanı en az zararla atlatması ve gelişiminin asgari düzeyde etkilenmesi için verilecek olan velayet kararı çok büyük önem taşımaktadır. Boşanma davalarında çocuğun velayetinin hangi ebeveyne verileceğinin belirlenmesinde göz önünde bulundurulması gereken önemli unsurlardan biri de ebeveynlerin ebeveynlik kapasitesinin değerlendirilmesidir. Makalemizde ebeveynlik kapasitesi değerlendirmesi için kullanılabilecek objektif ölçütlerin neler olabileceği tartışılmaktadır. Değerlendirmede kullanılabileceği savunulan iki (Parenting Skils Assessment-10 ve Parenting Competence 3) aracın özellikleri irdelenmiştir.

\section{Ebeveynlik ve Ebeveynlik Kapasitesi}

Ebeveynin görevi çocuğu hem ebeveynin kendisinden hem de toplumdan kaynaklanabilecek zararlardan (Fakirlik, hastalık, yetersizlik ve ahlaksızlık gibi) korumak çocuğun gelişimi için uygun şartları sağlamak ve ihtiyaçlarını karşılamaktır (6). Jackson (7) ebeveynliği "Bebeklikten yetişkinliğe kadar çocuğun fiziksel, duygusal, sosyal ve entelektüel gelişimini destekleme ve bu yeteneklerin gelişimine yardımcı olma kabiliyeti” olarak tanımlar. Donald ve Jureidini (6) ise daha basit bir ifadeyle "Çocuğun ihtiyaçlarını anlayabilme ve önceliği ona verebilme kabiliyeti” olarak tanımlamaktadır.

Bir çocuğun gelişimini sağlıklı bir biçimde tamamlayabilmesi için ebeveyn, ebeveynliğin gereklerini yerine getirebilmelidir. Ebeveynin ebeveynlik becerilerini uzun dönemde "yeterince iyi” şekilde yerine getirebilme düzeyi ebeveynlik kapasitesi olarak adlandırılır (8). Bu kapasite çocuğun gelişimine doğrudan etkilidir ve ebeveynlik kapasitesi düzeyiyle çocuğun sağlıklı gelişimi arasında bir korelasyon vardır (9).

Ebeveynlik kapasitesi Hoghhuugie tarafindan 3 başlikta toplanmıştır:

1. Bakım yeteneği (Çocukların fiziksel, duygusal, sosyal durum ve ihtiyaçlarını karşılayabilme onları hastalık zarar kaza veya istismardan koruma).

2. Kontrol yeteneği (Uygun bağları kurma ve bunu devam ettirme).

3. Çocuk yetiştirme yeteneği (Çocuğun farklı alanlarındaki potansiyelinin farkında olma).
Ebeveynin bu becerileri yeterli düzeyde yerine getirebilmesi için ihtiyacı olan özellikler ise;

1. Bilgi (Çocuğun ihtiyaçları en iyi nasıl karşılanır, çocuğun gelişimsel potansiyeli, çocuğa zarar verebilecek kaynakları ve bu kaynaklar hakkında ipuçlarını ve bunlara nasıl müdahale edeceğini bilme).

2. Motivasyon (Çocuğu koruma ve kendi kişisel ihtiyaçlarından ödün verme)

3. Kaynak (Hem maddi hem de manevi) .

4. Fırsat ve zaman olarak belirtilmiştir (8).

Başka bir araştırmada ebeveynlik kapasitesinin 6 ana bileşenden oluştuğu belirtilmiştir;

1. Anlama/Sezgi: Ebeveynin çocuğu bir birey olarak görmesi ve onun ihtiyaçlarını anlayarak bunları karşlayabilme yeteneği.

2. Gönüllü istek ve Kabiliyet: Uzun dönem sürdürülebilen bir motivasyon ve kabiliyet.

3. Günlük ve sürekli ihtiyaçları karşılayabilme: Çocuğun gelişim süreci içinde hem süreklilik gösteren hem de çocuğun içinde bulunduğu döneme göre değişen ihtiyaçları anlayabilme ve karşılayabilme.

4. Çocuğun ihtiyaçlarını öncelikleme: Ebeveyn çocuğun kendisine bağımlı bir birey olduğunun farkında olarak fedakârlık yapabilme.

5. Ebeveyn-Çocuk bağı: Çocukta güven ve konfor hissi oluşturacak ve özgüvenini artıracak bir bağ kurabilme.

6. Devamlılık/Tutarlılık ve Esneklik: Ebeveynin davranışlarında tutarlı olmanın yanı sıra duruma göre davranışlarında tolerans gösterebilme (10).

Tanımlanmış olan bu ebeveynlik özelliklerinin dinamik olduğu, çocukla ebeveyn arasındaki ilişki sürecinde evrimleştiği yani ebeveynlik kapasitesinin olumlu veya olumsuz değişimlere açık olduğu unutulmamalıdır (8).

\section{Ebeveynlik Kapasitesinin Değerlendirilmesi}

Velayet davalarında çocuğun korunmasını sağlamak, ebeveynlerin çocuğun refahını sağlayacak düzeyde olup olmadığını belirlemek ve velayet hakkının kime verileceği konusunda bilimsel, objektif bir bilgi elde etmek için ebeveynlerin ebeveynlik kapasitesinin değerlendirilmesi gerekir $(5,11,12)$.

Değerlendirme için hâkim bilirkişiye başvurabilir, burada bilirkişinin düzenleyeceği raporun amacı velayet kararını verirken hâkime yardımcı olmaktır $(13,14)$. Yapılan değerlendirme, velayetin kime verilmesi gerektiğini belirtmekten çok ebeveynlerin var olan durumunu ortaya koyar.

Bilirkişi yapılan değerlendirmenin kısıtlllıkları ve değerlendirme ile elde edilebilecek /elde edilemeyecek bilgilerin farkında olmalıdır. Yani bir değerlendirme "An- 
nenin ebeveynlik becerileri nelerdir?" veya "Anne- babanın duygusal ve kognitif fonksiyonları ne durumda?" sorularını cevaplamak yerine ebeveynlik becerilerinin ve kişisel özelliklerin ebeveynlik pratiğine etkisini ortaya koyar (15).

Ebeveynlik kapasitesi değerlendirmesiyle elde edilebilecek ve edilemeyecek bilgiler şunlardır:

\section{Elde edilebilecekler;}

1. Ebeveynlerin karakteristik özelliklerini tanımlamak,

2. Ebeveyn olarak çocuğun yetiştirilmesinde yetkinliklerini ölçmek,

3. Ebeveynlerin anormal ve sorunlu davranışlarını ve değiştirilebilirliğini göstermek,

4. Kişiye özel ve çevresel şartların ebeveynin davranışlarına olumlu ve olumsuz etkilerini göstermek,

5. Çocuğun var olan durumu, ihtiyaçları ve ebeveynlerin yetenekleri ve eksikliklerinin çocuk için oluşturduğu riskleri belirlemek,

6. Hangi unsurların müdahale ile iyileştirilmesinin mümkün olduğunu belirlemek.

\section{Elde edilemeyecekler;}

1. Ebeveynlik standartlarına göre ebeveynleri karşılaştırmak,

2. Dolaylı parametrelerle ebeveynin yeterliliği hakkında sonuçlar çıkarmak,

3. Ebeveynlik kapasitesini mental sağlik durumuyla tahmin etmek,

4. Duruma özel etkileri değerlendirme dışında tutmak,

5. Şu anki duruma bakarak gelecekteki davranışlar hakkında karar vermek,

6. Mahkeme tarafindan sorulmayan sorulara cevap vermek (11).

Çocuğun korunması bağlamında yapılan ebeveynlik değerlendirmesi ebeveynlerin klinik değerlendirmelerinden veya ebeveynlik eğitiminden farklı bir kavramdır çünkü bu değerlendirme adli süreçlerde kullanılacaktır. Birçok klinisyen bu konuda eğitimli değildir ve bu yüzden adli değerlendirmede hataya düşebilmektedir (15). Bilirkişi ebeveynlik değerlendirmesi konusunda tecrübeli ve eğitimli olmalıdır, aksi takdir de değerlendirme bilirkişinin önyargılarına kurban gidebilmektedir $(16,17)$.

Çocuğun velayeti ve refahı hakkında verilecek kararlar riskli ve kesin olmayan konular içerir. Değerlendirmeler çoğunlukla eksik-tartışmalı gerçekler, zaman kısıtlılığ1 ve öngörülemeyen bir geleceğe yönelik yapılır (15). Bilirkişi değerlendirmeye başlamadan önce; ebeveynler, çocuk ve aile hakkında ulaşabildiği tüm bilgi ve belgeleri elde edip incelemelidir $(8,9,11,14,15)$. Bu sayede değerlendirmenin süresi kısalacak ve değerlendirmenin odak noktası olması gereken konular açık bir şekilde ortaya çıkacaktır $(11,15)$. Bilgi ve belgeler; ebeveynler ve çocuğun tıbbi kayıtlarından, eğitim ve iş hayatlarını geçirdikleri kurumlardan ve buralarda çalışanlardan ve kendi arkadaş-akraba-komşu çevreleriyle yapılan görüşmelerden elde edilebilir $(14,17)$.

Bilirkişi; değerlendirmenin amacını ve hangi konularda yoğunlaşması gerektiğini belirlemelidir (5). Bu konular; ebeveynlerin birbirleri hakkındaki iddiaları, endişeleri, aile, ebeveynler ve çocuğun şu anki durumu ve geçmişleri ve çocuk-ebeveyn ilişkileri olabilir.

Ebeveynlik kapasitesi değerlendirmesinde bilirkişi tarafından değerlendirilebilecek olası maddeler ve değerlendirmede kullanılabilecek yöntemler/kaynaklar çeşitli kaynaklarda sayılmıştır.

\section{Ebeveynlik kapasitesi değerlendirmesinde bilirkişi} tarafından değerlendirilebilecek olası maddeler;

1. Çocuğun ihtiyaçları ve bunların karşılanma düzeyi $(9,15,18)$,

2. Ebeveynlerin özellikleri: Yetenekler, eksiklikler, deger yargiları $(9,12,13,15,16,18)$,

3. Ebeveynlerin ebeveynlik geçmişleri ve çocuğun yetiştirilmesine katılımları (16),

4. Ebeveynin geçmişi (İstismar ve ihmal hikâyesi) $(11,12,16)$,

5. Ebeveynin madde kullanımı $(13,19)$,

6. Çocuk ve ebeveynlerin fiziksel ve mental sağlık durumları $(9,12,13,16-18)$,

7. Çocuk-Ebeveyn ilişkileri $(9,13,14,18,19)$,

8. Aile içi ilişkilerin geçmişi ve ailenin şu anki durumu $(16,18,19,20)$,

9. Ailenin yaşadığı ortam, çevre (20),

10. Ailenin sosyo-ekonomik durumu $(11,20)$,

11. Sosyal destek alıp almamaları ve destekten efektif yararlanıp yararlanmama $(18,19)$,

\section{Bilirkişi değerlendirme sürecinde bilgi edinme ve değerlendirme için kullanabileceği yöntemleri/ kaynaklar;}

1. Ebeveynler ve çocuk/larla yapılan birebir görüşmeler $(9,11,14,16,17)$,

2. Her ebeveynin ayrı olarak çocukla etkileşim halinde olduğu görüşmeler ve gözlemler $(9,11,15,17,18,21)$,

3. Ev veya işyerleri gibi ailenin doğal yaşam ortamlarında yapılan gözlemler $(11,17,21)$,

4. Ailenin, ebeveynlerin ve çocuk/ların günlük yaşamını gösteren ses veya görüntü kayıtları $(9,16,17)$,

5. Psikolojik ve mental durum değerlendirme testleri $(9,11,12,14,16,19)$

6. Ebeveynlik kapasitesi değerlendirmede kullanılan standart formlar $(11,17)$. 
Literatürde ebeveynlik kapasitesi değerlendirmesinde profesyoneller tarafından aktif olarak kullanılan çeşitli değerlendirme araçları vardır. Bu araçlar birbirlerinden küçük farklılıklar gösterebilmektedir. Genellikle değerlendirmede hangi aracın kullanılacağı bilirkişinin insiyatifine bırakılmıştır ancak aracın uygulandığı toplumun yapısına uygunluğu gözetilmelidir.
Değerlendirme araçlarından Ebeveynlik Becerileri Değerlendirmesi (The Parenting Skills Assessment-PSA) Ebeveynlik Becerileri Değerlendirmesi ve Ebeveynlik Yeterliliği (Parenting Competence 3-PC3) Ebeveynlik Yeterliliği velayet davalarında sık kullanılan ikisidir. PSA, 5 ana başlık ve 25 alt başlıktan (Tablo 1) PC3 ise 3 ana başlık ve 9 alt başlıktan oluşmaktadır (Tablo 2).

Tablo 1. Ebeveynlik Becerileri Değerlendirmesi (The Parenting Skills Assessment-PSA).

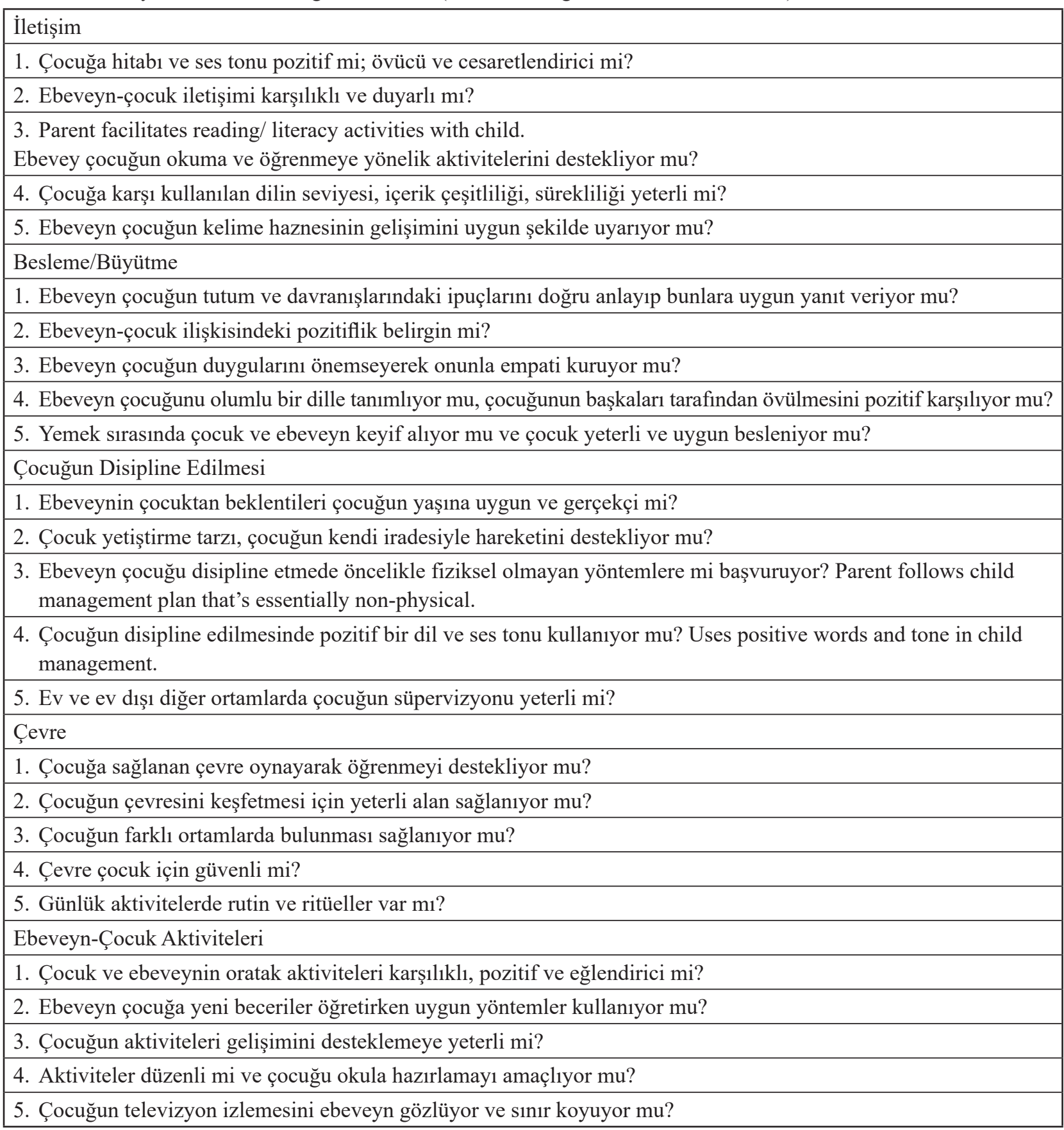


Tablo 2. Ebeveynlik Yeterliliği (Parenting Competence 3- PC3).

Çocuk yetiştirme becerileri

1. Ortak-ilgi (alaka)- fiziksel iletişim kurmak ve ilgilenmek, çocukla birlikte aktivitelerde yer almak; çocuğun davranışlarını onaylamak ve desteklemek.

2. Duyarlılık - çocuğun kendini ifade ederken gösterdiği davranışlar ve ilgili ipuçlarına duyarlılık göstermek; çocukla empati kurmak; çocuğa duygularını anlama ve ifade etme konusunda yardımcı olmak.

3. Koruma- çocuğun fiziksel, duygusal ve kognitif gelişimine yönelik kaynaklar sağlamak; ebeveynin beklentilerinin çocuğun gelişimine uygun olması; fiziksel, duygusal ve sosyal olarak güvenliğini temin etmek

Öğretme Kabiliyeti

1. İletişim - beklentiler, kurallar ve değerler konusunda açık olmak; etkin bir şekilde dinlemek; yükses sesli, talepkar, tehdit içerikli ya da düşmanca konuşma gibi olumsuz diyalogları asgari düzeyde kullanmak; problem çözme ve eleştirel düşünme becerilerini öğretmek.

2. Yönetim - birtakım rutinler yapılandırmak; eğitim hayatını, sosyal çevreyi ve bu sosyal çevrelerle ilişkisini -internet ve medya kullanımı da dâhil - çok müdahil olmadan izlemek.

3. Disiplin- gelişimsel düzeyine uygun amaçlar belirlemek; çocuğa yönelik kuralların, sınırların ve beklentilerin açık ve devamlı olması. Çocukla iletişimde beklentilerin sonuçların belirgin olması; Disiplin sürecinin övgü ve olumlu yaptırımları içermesi

4. Modelleme - duygu-durum yönetimi, dürtü kontrolü (örn: öfke, duygu-durumu değişim esaslarının kullanımı), kurallara riayet, çatışma yönetimi, zaman yönetimi.

Ortak Ebeveynlik Yetenekleri

1. Diğer ebeveynle, çocuğun tıbbi ihtiyaçları, okuldaki performansı, rekreasyonal aktiviteleri, arkadaşları, disiplinle alakalı konuları, günlük rutini vs. ile ilgili olarak iletişim içersinde olmak.

2. Çocuğun, diğer ebeveynle olan ilişkisini, diğer ebeveynle alakalı eleştiri yapmaktan kaçınarak güçlendirmek; diğer ebeveynin otoritesini desteklemek; çocuğa bakmak için yapılan zaman paylaşımı programında esnek davranmak, diğer ebeveynin kaynaklarının ve iyi niyetinin farkında olmak; ilişkiyi, diğer ebeveynin geniş ailesi ve sosyal ağıyla desteklemek.

\section{4. Çocuğun ihtiyaçları ve bunların karşılanma düzeyi}

Çocuğun yaşına ve gelişim durumuna göre değişen ihtiyaçları; ebeveynlerin de farklı davranış ve yetenekler sergilemesini gerektirir $(6,8,11,19)$ Fakat her çocuğun yetişkinliğe kadar değişmeyen ihtiyaçları da vardır. Çocuğun güvenliği bunların başında gelir, bu nedenle değerlendirme çocuğun güvenliğini temel almalı ve hangi ebeveynin bu konuda daha uygun olacağını belirlenmelidir (22).

Ebeveynin çocuğa ayırdığı zaman, onunla kurduğu iletişim, çocuğa sunabildiği ekonomik kaynaklar vs. çocuğun ihtiyaçlarının karşılanma düzeyiyle ilgilidir. Çocukla daha fazla zaman geçiren ve özel aktiviteler (konuşma, oyun oynama, beraber spor veya hobiler yapma) yapan ebeveynler daha olumlu ebeveynlik pratiği göstermektedir (20). Bilirkişi hangi ebeveynin çocuğa daha fazla vakit ayırdığını ve beraber geçirilen zamanın çocuğun gelişimi için ne kadar faydalı olduğunu değerlendirmelidir. Mesela gece çalışan bir ebeveyn sabahları okula giden çocuğuyla fazla zaman geçiremeyeceği için onun ihtiyaçlarının farkında olmak ve bu ihtiyaçları karş1lamakta elbette zorlanacaktır.

Çocuğun ihtiyaçlarının karşılanma düzeyi hakkında bilgi edinme amacıyla çocukla yarı yapılandırılmış görüşmeler yapılmalıdır (9). Bu görüşmeler çocuğun yaşı uygunsa çocukla yalnız başına ve en az iki kez yapılır (14). Görüşmelerde çocuğa doğrudan hangi ebeveynin ebeveynlik yeteneklerinin daha iyi olduğunu sormak yerine ebeveynlerle ilişkisi sorulmalıdır. Ebeveynlerin çocuk üzerinde baskı kurmuş olabileceği, bu nedende çocuğun duyduğu suçluluk, korku hissinin bilirkişiye söyleyeceklerini etkileyeceği unutulmamalıdır (14).

\section{Ebeveynlerin özellikleri: Yetenekler, eksiklikler, değer yargıları}

Ebeveynlik bir inanç, davranış ve pratikler bütünüdür ve ebeveyn bu maddeler çerçevesinde kendi ebeveynlik becerilerini geliştirir (9). Etkin bir değerlendirme; çocuğun ihtiyaçlarını ön plana alarak ebeveynin becerilerini, 
eksikliklerini, bu ebeveynlik özelliklerinin oluşmas1na katkı sağlayan kişisel değerlerini ve bunların kişinin ebeveynlik pratiğine olan etkisini ortaya koyar $(9,14)$. Örneğin; ebeveyn kendi inançlarından dolayı çocuğunu disipline etmek için fiziksel cezalandırmayı normal bir davranış olarak görebilir ve çocuk bu durumdan hem fiziksel hem de duygusal zarar görebilir (9).

Ebeveynliği oluşturan temel faktörler dışında kişinin ebeveynlik kapasitesini etkileyen sosyal, ekonomik, politik ve kültürel faktörler de vardır. (11) Kültür bu faktörlerin en önemlilerinden birisidir ve ebeveynlik pratiğine doğrudan etki eder. Mesela bir infanta nasıl bakılacağ1 (Türk toplumunda -zararlı bir yöntem olduğu tıbben bilinen- bebek kundağ 1 kullanımı vb.) değerlendirilirken ebeveynin ait olduğu toplumsal kültür göz önüne alınmalıdır (11). Kültürel farklılıklar ebeveynlik ve ebeveynlik kapasitesi tanımını hatta değerlendirmenin yönünü değiştirebilir. Bazen de bilirkişinin olumsuz sonuçlar doğuracağını düşünebileceği ebeveyn davranışları çocuğun gelişimini olumlu etkiliyor olabilir (8). Örnek olarak; aşırı kontrolcü ebeveyn anglo-sakson kültüründeki çocuklar tarafından düşmanca ve uzaklaştırıcı bir tavır olarak algılanırken Kore'li çocuklar bunu sıcaklık ve sevgi göstergesi olarak algılamışırır (19).

Ebeveynlik uzun bir süreç olduğu için bazı özel yetenekler de gerektirmektedir; stresle baş etme yeteneği, güdü (impulse) kontrol yeteneği ve self regulation yeteneği bunlar arasında sayılabilir. Bu yetenekler doğrudan veya dolaylı olarak ebeveyni ve aileyi etkileyerek çocuğa rol model oluşturabilir (19). Stresle baş etme yeteneği düşük olan bir ebeveyn bunu çocuğuna yansıtarak çocuğa kötü muamele edebilir. Bu durum çocuğun ileriki hayatında sosyal izolasyona neden olabilir (19).

Değerlendirme çocuk ve ebeveynin beraber gözlemlenmesini içermelidir. Ebeveyn-çocuk gözlemi ev ve işyeri gibi ortamlarda yapılabilir, hatta ev içi çekilen videolar da değerlendirmeye katkı sağlayabilir (9). Gözlemler bilirkişiye iki önemli avantaj sağlar; ebeveyn, yapabileceği en iyi ebeveynlik pratiğini sergilemeye çalışacağ için ebeveynin tam kapasitesi görülebilir ve ebeveynle çocuk farklı şartlar (stres, değişik ortam gibi) altında görülmüş olacağ 1 için değerlendirme daha sağliklı olur (15). Bu gözlemlerin kapsamlı olabilmesi için en az 90 dakika sürdürülmesi önerilmektedir (9).

Ebeveynler hakkında toplanan belgeler değerlendirmede oldukça kullanışlı olabilir. Mesela öğretmen olan bir ebeveynin çocuğun okul hayatına katkısının daha fazla olacağ 1 , hemşire olan ebeveynin çocuğun sağlık problemleriyle daha iyi başa çıkabileceği veya tam tersi bir durum olarak; trafikte kuralları sıkça ihlal eden bir ebeveynin çocuk velayeti için kurallara uyan ebeveyne göre daha kötü bir tercih olacağı öngörülebilir (9).
Çocukla iletişimde kullanılan dilin içeriği, ses tonu ve ebeveynlerin çocuğa davranışları değerlendirmenin önemli başlıklarından biridir. Çocukla iletişimde kullanılan dil olumlu ögeler içermeli ve onun gelişimini desteklemelidir. Bununla birlikte çocuğun davranışlarına karş1lık olarak ebeveynin verdiği yanıtlar da çocuğun sosyal gelişiminde önemlidir, çocuk uygun veya uygun olmayan bir davranış sergilediğinde ebeveyn bunlara göre fark11, uygun yanıtlar vermeli ve bu yanıtlar çocuğun yaşı, gelişim seviyesi ve konuya göre farklılık ve esneklik arz etmelidir (19). Mesela; ebeveyn çocuğunu disipline etmek için akşam 22.00'dan sonra dişarı çıkmasına izin vermeyebilir fakat özel bir etkinliğe katılacak olan çocuk için ebeveynin bu kuralı esnetebilmesi ebeveyn-çocuk ilişkisine olumlu yansıyacaktır. Ebeveynin çocuğun davranışlarına tepkisiz kalıp, bakımı konusunda duyarsız, anlayışsız bir tavır takınmasıysa çocuğun fiziksel, duygusal ve sosyal gelişimini olumsuz yönde etkilemektedir (19).

\section{Ebeveynlerin ebeveynlik geçmişleri ve çocuğun yetiştirilmesine katılımları}

Görüşmelerde, bilirkişi ebeveynlerin ebeveynlik geçmişini (9), dava öncesi çocukla olan iletişimlerini, ilişkilerini, çocuğun bakımı konusunda üstlendikleri rolü (15), bu rolün şu anki durumunu sorgulamalı ve ebeveynin çocuk için koruyucu bir faktör mü yoksa risk mi olduğunu ortaya koymalıdır (17).

Her ebeveyn ve çocuk arasında çocuğun gelişimi sürecinde ebeveyn tarafından uygun bir bağ geliştirilmelidir. Bu bağ ebeveyne; çocukla arasındaki ilişkiye çocuğun gözünden bakabilme firsatı verir. Çocuk bu bağ sayesinde ebeveynin yanında güvende olduğu hissini edinir. Bu bağın olmaması veya uygunsuz olması çocuğun güven duygusunu zedelediği gibi o anda ve gelecekteki hayatında kuracağ 1 ilişkilere de zarar vermektedir (19). Ebeveyn ve çocuğun birlikte olduğu görüşmelerde çocuğun gösterdiği olumsuz (uygunsuz) davranışlar bu bağın yokluğunu veya uygunsuzluğunu gösteren ipuçlarıdır ve bilirkişi bu ipuçlarını fark edebilmelidir (19).

Dava sürecinde ve yapılan görüşmelerde ebeveynlerin davranışları değişebilir, mesela baba çocukla daha ilgili gözükebilir, fakat gelecekteki davranışlarını öngörmek için en iyi yol babanın çocuğa karşı geçmiş davranışlarına bakmaktır (23). Bu konudaki bilgiler de yine aile dışı kişilerle yapılan görüşmelerden ve kayıtlardan elde edilebilir.

Genelde görüşme yapılan ebeveyn iyi bir ebeveyn portresi çizmeye uğraşır ve testlerde arzulanan cevapları verir $(14,21)$. Ebeveynler dürüst olması konusunda uyarılmalı ve bu yaptıklarının değerlendirmenin güvenilirliğini etkileyeceği belirtilmelidir. İyi bir bilirkişi hangi ebe- 
veynin dürüst davrandığını ve ebeveynlerin cevaplarının gerçekçi olup olmadığını anlayabilmelidir (14).

Ebeveynlerin yapılan görüşmelerde diğer ebeveyn hakkında olumsuz iddia ve görüşler belirtebilir, bunlar en az iki kaynakla doğrulanmalıdır (16); mesela çocuğun diğer ebeveyn tarafından şiddete maruz kaldığı iddiası gibi iddialar doğrulanmadığı veya yanlışlığı ortaya konmadığı takdirde değerlendirmeyi yanlış sonuçlar elde edilmesine yol açar.

\section{Ebeveynin geçmişi (İstismar ve ihmal hikâyesi)}

Değerlendirme ebeveynin kendi gelişimi hakkında da bilgiler içermelidir (12) Araştırmalar ebeveynlik becerilerinin ebeveynin kendi geçmişiyle alakalı olduğunu göstermektedir (19). Bilirkişi ebeveynin ebeveynlik kapasitesine odaklanmanın yanı sıra ebeveynin ebeveynlik hakkındaki düşünceleri ve kafasındaki ebeveynlik rolünün ne olduğunu da değerlendirmelidir (24). Bu değerlendirmeler ebeveynin ebeveynlik konusundaki algısı ve kendi çocuğuna daha uygun bir ebeveyn olmak için ne yaptığı/yapacağı konusunda bir gösterge olabilir. Mesela ebeveyn kendi ebeveynlerinden gördüğü şiddet uygulamasını normal karşılayıp "bana bir şey olmadı, çocuğuma da bir şey olmaz" diyerek çocuğuna şiddet uygulamayı normal karşılayabilir, ya da tam tersi olarak "şiddet benim gelişimime hiçbir katkı sağlamadı bu yüzden kendi çocuğuma şiddet uygulamayacağım” da diyebilir (19).

Çocuklukluğunda istismara maruz kalan ebeveynlerin \%25-35'in kendi çocuklarına da istismar uygulamaktadır. Bunun yanısıra istismar-ihmalci ebeveynler çocuklarına karşı genel olarak daha az uyarıcı ve olumlu davranış sergilerler (19). Ebeveynlerin çocukken cinsel veya duygusal istismara uğraması ile kendi çocuklarına bunu yansıtmaları arasında düşük risk bulunmuş olsa da ebeveynin çocukluktan gelen travması mental problemlere neden olmakta ve çocuğunu istismar etme olasıllğını arttırmaktadır. Çocuklukta yaşanan bir istismarın bastırılmış sonuçları yetişkinlikte yaşanan bir travma sonucu ortaya çıkabilecek stres veya bulgunun şiddetini de arttırabilmektedir (18).

\section{Ebeveynin madde kullanımı}

Madde kullanımı çocuk ebeveyn ilişkisini bozan etkenlerdendir. Mesela antidepresan ilaç kullanımının çocuğa olan duyarlılıkta azalmaya ve çocuktan uzaklaşmaya neden olduğu görülmüştür, ayrıca uzun dönem madde kullanımı nörolojik etkiler sonucu hafıza ve dikkat süreçlerini etkileyerek ebeveynlik kapasitesinin düşmesine de neden olabilmektedir (19).

Ebeveynin mental sağlık durumu madde kullanımı ile beraber mutlaka değerlendirilmelidir. Madde kullanımı ebeveynlerde nörolojik bozukluklar (Hafiza bozukluğu, dikkat eksikliği gibi) sonucu ikincil olarak ebeveynlik kapasitesini düşürebilir (19). Ebeveynlerinde nörolojik bozukluk olan çocukların psikolojik sorunlar yaşama ihtimali artmaktadır (13).

Araştırmalar madde kullanımında olduğu gibi alkol bağımlılığın da çocuğun gelişimini kötü yönde etkilediğini göstermektedir. Ayrıca madde kullanımının bırakılmasının da ebeveynlik becerilerinde olumlu yansımalarının olduğu görülmektedir (19).

\section{9. Çocuk ve ebeveynlerin psikolojik, fiziksel ve mental sağlık durumları}

Ebeveynin kognitif ve psikolojik durumu değerlendirmenin merkezinde olmalıdır (13). Velayeti alan ebeveynin psikolojik olarak iyi olması çocuğun gelişim sürecini iyi geçireceğinin en önemli göstergelerinden birisidir. Çocuğa sıcak davranan, onu destekleyen, yeterli disiplini sağlayan, çocuğun yaşına uygun beklentileri olan, çocukla iletişimi iyi olan ve bu konularda sürekliliği sağlayan ebeveyn çocuğun boşanma süreci ve sonrasını en iyi şekilde atlatıp gelişimini sağlıklı sürdürmesini sağlayacaktır (5).

Entelektüel kapasite düşüklüğü ve psikiyatrik sorunlar eskiden ebeveynlik kapasitesinin yokluğuna karar vermek için yeterli sayılıyordu ama artık bu görüş doğru kabul edilmemektedir, Çalışmalar hastalığın derecesini ve bunun ebeveynlik kapasitesine etkilerinin farklı olabileceğini göstermektedir $(18,19)$. Entelektüel kapasitesi düşük ebeveynlerin çevrelerinden aldığı sosyal destekle ebeveynlik becerilerini yeterli düzeyde yerine getirebildiği görülmüştür (19).

Ebeveynin önceden var olan depresyon, şizofreni gibi majör mental hastalıklar veya boşanma sonrası gelişen psikolojik sorunlar ebeveynlik kapasitesini dolaylı olarak etkileyebilir. (13,20,25). Boşanmış annelerde yapılan bir araştırma bu annelerin daha sıkı ve otoriter bir ebeveynlik tarzı sergilediği ve çocuğun problemlerini anlamada eksiklik gösterip çocuğu ihmal ettiklerini ortaya koymuştur (20). Hastalıkların yanında aile içinde olan diğer problemler bu hastalıkların çocuğa etkisini değiştirebilir. Mesela aile içi şiddet olan ailelerden; annesinde depresyon olan çocuklar uygun olmayan davranışlar geliştirmişlerdir (19). Tek başına velayetin aksine ortak velayet hakk1 olan ebeveynlerde psikolojik hastalıklar daha az görülmektedir (20).

MMPI-2, PAI ve MCMI-III gibi kişilik bozukluklar1 ve psikiyatrik hastalıkların belirlenmesinde kullanılan testler kişilerdeki psikolojik rahatsızlıkları tanımlayabilir fakat hastalık ve bozuklukların ebeveynlik kapasitesini ve çocuğun gelişimini nasıl etkileyeceği ancak ebeveynlik kapasitesi değerlendirme testleriyle ortaya konabilir (9). 
Psikiyatrik hastalığ olan ebeveynin bu konuda tedavi alıp almadığı, alıyorsa bu tedavinin yetelriliği de değerlendirilmelidir. Bunun dışında iki ebeveynli ailelerde bir ebeveyn hasta diğeri sağlamsa sağlam olan ebeveynin tamponlayıcı etkisi veya tek ebeveyn olan ailelerde geniş aile ve sosyal çevrenin desteği de değerlendirmeye katılmalıdır (19).

Boşanmış ailelerin çocuklarının psikolojik iyilik durumlarında bozulma (Depresyon, Anksiyete vb.), akademik başarıları ve sosyal uyumlarında diğer çocuklara göre düşüş göstermektedir. Bu olumsuz etkiler çocukların yetişkinlik hayatlarına ve hatta evlilik hayatlarına da etki etmektedir. Wallerstein ve Lewis araştırmalarında 25 yıl sonra bile çocukların (şimdiki erişkinlerin) şok, şaşkınlık, mutsuzluk, yalnızlık ve sinirlilik duygularının hala devam ettiğini ve boşanmanın akut bir stresörden ziyade ömür boyu süren bir deneyim olduğunu belirtmiştir (5).

Boşanma sonrası çocuğa psikolojik olarak pozitif etki eden durumlar

- Velayet hakkını alan ebeveynle iyi ilişki içinde olmas1

- Diğer ebeveynle iyi ilişki içinde olması

- Ebeveynler arası çekişmenin minimal olması/hiç olmaması ve çocuğu içermemesi

- Çocuğun ekonomik olarak güvende olması şeklinde belirtilmiştir (13).

Çocuğun duygusal, davranışsal ve sosyal fonksiyon değerlendirmesi yapılmalıdır. $\mathrm{Bu}$ değerlendirme zeka testleri, davranış bozuklukları değerlendirmeleri, gözlemler, çocukla görüşmeler ve çocuğun öğretmeni gibi 3. kişilerle de görüşülmelidir (13).

\section{0. Çocuk-Ebeveyn ilişkileri}

Ebeveyn ve çocuk ilişkisinin gözlemlenmesi ebeveynin becerileriyle ilgili olan ve görüşmelerde ölçülemeyen güçlü ve zayıf yanlarını görmeyi sağlar (12). Gözlemin asıl amacı ebeveyn ve çocuk etkileşimini daha iyi görebilmektir. Gözlemlerde odaklanılması gereken noktalar: duygusal bağ, iletişim yetenekleri, çocuktan olan beklentilerin gerçekçiliği, oyuncakların çocuğa uygunluğu vb. gibi şeylerdir. Gözlem görevi serbest oynamay1, çocuk ve ebeveynin birlikte yaptığ 1 görevleri ve problem çözme yeteneklerini gözlemlemeyi içerir (11).

Ebeveynin günlük performansta davranışları ve yetenekleri değerlendirilmelidir (15). Bunun yanında ailenin yemek zamanlarını, ebeveynin çocuğun ödevlerine yardım ettiği zamanları ve temizlik zamanlarını gözlemlemek de ebeveynin günlük görev performansını değerlendirmede yardımcı olacaktır (9).
Ebeveyn çocuk etkileşimi sırasında ebeveyn hakkında bazı bilgiler edinilir: ebeveynin çocuğun gelişimsel seviyesini anlayıp anlamadığı, çocuğun ihtiyaçlarını fark edip etmediği ve bunları karşılayıp karşılamadığı ve çocuğun kendi fikirlerini açıklamasına izin verip vermediği gibi (15).

Ebeveynlik kapasitesi temel bakımı karşılayabilme, duygusal sıcaklık sağlama, stabil davranış sergileme ve bağ kurmayı içerir (24).

Bilirkişi iki ebeveynle de çocukla beraberken ayrı ayrı görüşmeli ve ebeveyn çocuk etkileşimini gözlemlemelidir. Görüşmeler evde de olabilir fakat çoğu bilirkişi görüşmeleri ofislerinde yapmaktadır (17).

Ebeveynin yeni bir partneri varsa onla da görüşülmeli ve çocukla etkileşimi gözlemlenmelidir (14).

\section{Aile içi ilişkilerin geçmişi ve ailenin şu anki durumu}

Boşanma ebeveynler arasında çekişmeye yol açabilmektedir. Çekişme boşanmadan önce başlayıp sonraki süreçte de devam edebilir (5). Çekişme ebeveynlik kapasitesine olumsuz etki etmekte (23) ve ebeveynler arasında çocuk bakımı konusunda işbirliği azalmaktadır (25). Ebeveynler arasında olan bu çekişme çocuğu da olumsuz etkilemekte ve çocukta stres yaratarak kısa ve uzun dönemde depresyon, anksiyete gibi psikolojik sorun gelişme ihtimalini arttırmaktadır (13). Çekişme sürecinde ebeveynlerden biri çocuğu diğer ebeveyne olumsuz mesajlar taşıma aracı olarak görebilir veya çocuğun diğer ebeveynle ilişkisini kesmek isteyebilir, bu deneyimler de çocuğun psikolojisine olumsuz olarak yansımaktadır (5). Bazı çekişmeli boşanmalarda baba aileden uzaklaşabilir, bu ailelerde anne daha sert ve disiplinli bir ebeveynlik tarzı benimseyip çocuğa gereken sıcaklığı göstermeyebilir. $\mathrm{Bu}$ durum annenin ebeveynlik kapasitesinde düşüşe neden olup çocuğun gelişim sürecinde ihtiyacı olan samimiyet ve destekten mahrum kalmasına yol açabilir (5).

Ebeveynler arasındaki çekişmenin çocuğun gelişimini etkileme oranları değişiklik gösterir, daha az etkilediğ durumlar;

- Çekişme adece ebeveynler arasında sürdüğünde, çocuğu içermediğinde ,

- Siklı̆ğ az olduğunda,

- Duygusal veya fiziksel ögeler içermediğinde veya az içerdiğinde,

- Çözülebildiğinde,

- Çocukla veya çocuk bakımıyla ilgili olmadığında şeklinde sıralanabilir (13).

Bilirkişi çekişmeye daha az katkıda bulunan ve davranışları ve psikolojik durumu daha stabil görünen ebeveyni belirlemelidir. 
Boşanma sürecinde olan bu çekişme genelde zamanla azalma eğilimindedir (13). Nefret tanımı ise daha farkl1dır. Çekişme kısa süreli basit bir durumken nefret motivasyonları olan ve uzun yıllar sürebilen ve temel olarak eşi kaybetmekten dolayı doğan yasa bağlı gelişen patolojik bir durumdur. Genelde boşanmadan sonraki 1. yılda ortaya çıkar ve 3 yıl içinde azalma eğilimindedir. Bu süreçte yalnız hisseden ebeveyn çocuğu kendi duygusal ihtiyaçları için kullanabilir, hatta bu durum uygun olmayan cinsel davranışlara, kışkırtıcılığa, aynı yatakta uyumaya ve beraber banyo yapmaya kadar varabilir. Bazı durumlarda ise ebeveyn diğer ebeveyni kontrol etmek veya ona zarar vermek için çocuğu kullanabilir. Bunun sonucunda çocuk kendisini çaresiz, güçsüz ve sadece kullanılan bir araçmış gibi hissedebilir (26). Bilirkişi çekişme ve nefret durumlarının farkında olmalı ve bunun çocukta yaratacağı psikolojik sorunları irdelemelidir.

\section{Ailenin yaşadığı ortam ve çevre}

Ebeveynin aile dışı ilişkileri de ebeveynlik kapasitesini etkiler. Mesela arkadaş ilişkileri az olan veya olmayan bir ebeveyn hem sosyal desekten mahrum kalacak hem de çocuğa rol model olabilecek kişilerden onu mahrum bırakacaktır (19). Arkadaş ilişkilerinde yanlış, zararlı fikir ve davranışları olan ebeveyn de çocuğun gelişimini kötü yönde etkiler. Arkadaş ilişkilerinde istismarcı ve şiddet eğilimli tavrı uygun bir davranış olarak gören çocuk bunu kendi hayatına taşıyabilir (19) Gözlemlerde aile ve çocuk ebeveyn ilişkileri hakkında bilgi sağlayabilecek kişiler evde bulunabilir (17). Bunlar ebeveynin arkadaş çevresi veya akrabaları olabilir. Bilirkişi bu kişilerin çocuğun gelişimine katkılarını ve katılımlarını da değerlendirmelidir (12).

Ev gözlemlerinde gözlemci evin durumu (temizliği, güvenliği gibi) çocuğa uygunluğu ve O’na sağladığ1 uygun alan hakkında da değerlendirme yapma imkânı bulabilir (17). Çocuğun yaşadığı ortamı değerlendiren bir sürü değerlendirme aracı vardır. Bunlar; ebeveynlerin yaşadığ 1 ortamın kalitesini (Çocuk için güvenlik sorunu oluşturan bir şey var mı yok mu?) ölçmeyi amaçlar (19). Çocuğun yaşadığı ortamda keşfetmesi için yeterli alan sağlanıp sağlanmadığı, çevrenin oyunla öğrenmeye uygun olup olmadığı ve çocuğun ev dişında farklı ortamlarda ne kadar zaman geçirebildiği değerlendirilmelidir (21).

\section{Ailenin sosyo-ekonomik durumu}

Ebeveyn birçok konuda çocuğa sağlayıcı ve destekleyici olması gereken kişidir. Bu durum özellikle çocuğun özel ihtiyaçları olduğu durumda gündeme gelir. Bu destek durumu ebeveynin dâhil olduğu sosyal sınıfa göre farklılık gösterir. Mesela çocuğun eğitim imkânları bunlardan en önemlilerindendir (19). Böyle bir durumda ço- cuğa daha yi eğitim olanakları sağlayabilen ebeveyn çocuğun velayeti için daha uygun bir seçim olacaktır.

Sosyal sınıf farklılıkları da ebeveynlik becerilerini çocuğun yaşadığı çevreyi uygun düzenleyememe sonucu ebeveynlik becerilerini etkileyebilir. Mesela; maddi geliri düşük bir ebeveyn çalışmaya daha çok zaman ayırmak zorunda kaldığı için çocuklarını çevresel risklerden korumaya yeterli zaman sahip olamayıp çocuk için sağlıklı ve koruyucu ortamı sağlayamayabilir (19).

Çocuğun boşanma sürecinde yaşadığ 1 bu olumsuz etkilere maddi gelir durumunda kötüleşme de katkıda bulunmaktadır $(5,25)$. Velayeti alacak ebeveynin geliri çocuğun refahı için önem arzeder. Gelirin yüksekliğiyle çocuğun refahı paraleldir (20).

Boşanma sonrası iki ebeveynin de harcaması gereken para artmaktadır, bu yüzden de daha fazla çalışmaları gerekebilmektedir. Bunun sonucu olarak çalışmaya harcanan zaman çocuktan çalınmakta ve ebeveynliğe ayrılan zaman azalmaktadır. Araştırmalar çalışan kadınların çocuklarına daha az kognitif ve sosyal uyarı verdiklerini göstermektedir. Ayrıca daha ucuz kira için ev değiştirme, çocuğu yaşadığ 1 yerden uzaklaştırma ve çocuğun maddi ihtiyaçlarını karşılayamama gibi çocuğu olumsuz etkileyen başka problemler de ortaya çıkabilmektedir (13).

\section{Sosyal destek alıp almamaları ve destekten efektif yararlanıp yararlanmama}

Ebeveynin aile dişı ilişkileri de becerilerini etkiler. Mesela aile dışında arkadaş ilişkileri az olan veya olmayan bir parent hem sosyal desekten mahrum kalacak hem de çocuğuna rol model olabilecek kişilerden çocuğunu mahrum birakacaktır (19). Sosyal izolasyon ve sosyal desteğin yokluğu ebeveynlik becerilerine kötü yansır, çocuk istismarı için ön ayak olur. Ebeveynler kendi arkadaş çevreleri ve sosyalleşme becerileriyle çocuğa örnek olur$\operatorname{lar}(19)$.

Ebeveynlerin kendi ilişkilerindeki kalite ebeveynlik yeteneklerine olumlu yansır. Daha tutarlı ve duyarlı ebeveynlik gösterirler (19). Arkadaş ilişkilerinde yanlış ve zararlı fikir ve davranışları olan ebeveyn de çocuğun gelişimini kötü yönde etkiler. Arkadaş ilişkilerinde istismarcı ve şiddet eğilimli tavrı uygun bir davranış olarak gören çocuk bunu kendi hayatına taşıyabilir (19).

Sosyal destek alma yeteneğinin değerlendirilmesi ebeveynlerin geçmişte ve şu andaki stres ve bunla başa çıkma yeteneğini de ölçmeyi sağlar. Stres ebeveynlik problemleriyle ve çocuğun istismar edilmesiyle doğrudan ilişkilidir. Aile içi şiddet çocuğun gelişimini negatif etkiler. Bilirkişi ebeveynlerin sosyo-ekonomik durumlarını göz önüne alarak olabilecek stresörleri değerlendirmelidir (19). 


\section{Sonuç}

Boşanma davalarında çocuğun velayeti hakkında verilecek karar büyük önem taşımaktadır. Uygun ebeveynle yetişmeyen çocuklarda psikolojik sorunlardan fiziksel gelişim bozukluklarına kadar istenmeyen durumlar gelişebilir. Ebeveynlerden hangisinin çocuğun refahı için daha iyi seçenek olduğunun belirlenmesi görevi mahkemenindir. Bu karar verilirken bilirkişi tarafından, objektif ölçütlerle hazırlanacak ebeveynlik kapasitesi değerlendirme raporu; verilecek kararın subjektif deliller yerine objektif ve bilimsel ölçütlere göre verilmesine yardımcı olacaktır. Bu araçlar, sadece velayetin kime verileceğinin değil, velayetin somut olguda hangi durumlarda kaldırılması gerektiğinin belirlenmesinde de veri sağlayıcı olarak kullanılabilir.

Yukarıda literatürde sık kullanıldığ 1 belirtilen standart yaklaşımlar değerlendirilmiştir. Bunlardan PSA 10'un konuya daha spesifik bilgi sağlama potansiyeli nedeniyle uygulamada daha iyi bir değerlendirme aracı olduğu kanaatindeyiz.

\section{Kaynaklar}

1. http://www.adlisicil.adalet.gov.tr/istatistik_2012/130.pdf Erişim Tarihi: 10.08.2015

2. Çocuk Haklarına Dair Sözleşme (http://www.unicef.org/ turkey/pdf/_cr23.pdf Erişim Tarihi: 10.08.2015)

3. Çocuk Koruma Kanunu. 5395. Kabul Tarihi: 3.7.2005. Resmi Gazete yayınlanma tarihi: 15.7.2005; Resmi Gazete Say1s1: 25876

4. Ailenin Korunması ve Kadına Karşı Şiddetin Önlenmesine Dair Kanun 6284. Kabul Tarihi: 8.3.2012. Resmi Gazete yayınlanma tarihi: 20.3.2012; Resmi Gazete Sayıs1: 28239

5. Portnoy SM. The psychology of divorce: A lawyer's primer, part 2: The effects of divorce on children. American Journal of Family Law. 2008;21(4):126-134.

6. Gough D, Stanley N. Parenting capacity. Child Abuse Review. 2004;13(1):1-4.

7. Seden J. Creative connections: Parenting capacity, reading with children and practitioner assessment and intervention. Child \& Family Social Work. 2008;13(2):133-143

8. Child Protection and Parenting Capacity Assessments; A Framework for Reducing Harm (http://www.childprotectionpartnership.org.uk/home/home.asp Erişim Tarihi: $17 / 08 / 2015)$

9. Moran JA, Weinstock DK. Assessing parenting skills for family court. Journal of Child Custody. 2011;8(3):166-188

10. Eve PM, Byrne MK, Gagliardi CR. What is good parenting? The perspectives of different professionals. Family Court Review. 2014;52(1):114-127
11. White A. Assessment of parenting capacity, Literature review. Ashfield New South Wales Sydney Australia, 2005

12. Harnett PH. A procedure for assessing parents' capacity for change in child protection cases. Children and Youth Services Review. 2007;29(9):1179-1188

13. Emery RE, Otto RK, O'Donohue WT. A critical assessment of child custody evaluations limited science and a flawed system. PsychologicalSciencein the Public Interest. 2005; 6(1):1-29

14. Bala N. Assessments for postseparation parenting disputes in Canada. Family Court Review. 2004;42(3):485-510

15. Budd KS. Assessing parenting capacity in a child welfare context. Decision Making in Child Welfare, Children and Youth Services Review. 2005;27(4):429-444

16. Stahl PM, Martin L. An historical look at child custody evaluations and the influence of AFCC. Family Court Review. 2013;51(1):42-47

17. Patel SH, Jones KD. Assessment of family custody issues using mental health evaluations: Implications for mental health counselors. J Mental Health Counseling. 2008;30(3):189-199

18. Schmidt F, Cuttress LJ, Lang J, Lewandowski MJ, Rawana JS. Assessing the parent-child relationship in parenting capacity evaluations: Clinical applications of attachment research. Family Court Review. 2007;45(2):247-259

19. Azar ST, Lauretti AF, Loding BV. The Evaluation of parental fitness in termination of parental rights cases: A functional-contextual perspective. Clinical Child \& Family Psychology Review. 1998;1(2):77-100

20. Cyr F, Di Stefano G, Desjardins B. Family life, parental separation, and child custody in Canada: A focus on Quebec. Family Court Review. 2013;51(4):522-541

21. Reed CS, Egeren LAV, McKelvey L. Psychometric Study of The Parenting Skills Assessment; A Practitioner Approach to Measuring Parenting Practices. Michigan State University Kellogg Center, Garden Level, East Lansing, Michigan, 2009

22. The protective capacity Assessment: Addressing Threats to Child Safety within the Case Plan (http://action4cp.org/documents/2005/pdf/Aug2005TheProtectiveCapacityAssessmentnowl.pdf Erişim Tarihi 17/08/2015)

23. Austin WG, Pruett MK, Kirkpatrick HD, Flens JR, Gould JW. Parental gatekeeping and child custody/child access evaluation: Part I: conceptual framework, research, and application. Family Court Review. 2013;51(3):485-501

24. Adshead G, Bluglass K. Attachment representations and factitious illness by proxy: relevance for assessment of parenting capacity in child maltreatment. Child Abuse Review 2001;10(6):398-410

25. Teubert D, Pinquart M. The association between coparenting and child adjustment: a meta-analysis. Parenting: Science \& Practice. 2010;10(4):286-307

26. Demby S. Interparent hatred and its impact on parenting: assessment in forensic custody evaluations. Psychoanalytic Inquiry. 2009;29(6):477-490 